\title{
The semi-complementizer shuō and non-referential CPs in Mandarin Chinese
}

\author{
Jiahui Huang*
}

\begin{abstract}
The empirical focus of this paper is the syntactic status of the semicomplementizer shuō grammaticalized from verbs of saying, in Mandarin Chinese. Such elements have been shown to exhibit atypical patterns compared to that in English, which triggers discussions of whether shuo should be analyzed as a complementizer (Paul, 2014; Huang, 2018). This paper presents novel data surrounding the distributional patterns of shuō and argues that shuō is a $\mathrm{C}$ head that introduces a subtype of CPs called non-referential CPs, following de Cuba (2017).
\end{abstract}

Keywords. complementizer; grammaticalization; CP; referentiality; Mandarin Chinese; finiteness; syntax

1. Introduction. The grammaticalization of verbs of saying (e.g. 'say') into complementizers, has been observed in a variety of languages across language families, including Indo-Iranian, Austronesian, Nakh-Daghestanian, Uralic languages, and Sino-Tibetan languages (Hock 1982, Klammer 2000, Heine \& Kuteva 2002, Chappell 2008, Burukina 2021). In Mandarin Chinese ${ }^{1}$, a well-documented candidate is the verb shuō (說), which not only retains its lexical meaning of 'say' as the main predicate (1a), but also exhibits behavior similar to that of the complementizer that in English in that it can occur in a position that follows matrix verbs and precedes clausal complements (1b) and (1c). Due to the preservation of the concrete lexical meaning of shuō, I called the shuō in Mandarin as a 'semi-complementizer' in this paper. (see Chappell (2008) for a detailed documentation of the grammaticalization of complementizers from verbs of saying in Sinitic languages, including waa6 in Cantonese, $\mathrm{ko \eta}^{51}$ in Taiwanese Southern Min.)
a. 張三 先 說
Zhāngsān xiān shuō
Zhāngsān first say
'Zhāngsān says first.'

b. 我 總是 覺得說 生活-裡 缺-了 點兒 什麼

Wǒ zǒngshì juéde shuō shēnghuó-lǐ quē-le diănr shénme

I always think say life-in lack-PERF little something

'I've always felt that there is something a little lacking in my life.' (Fāng 2006: 109)

c. 我 打算 說 到 英國 留學

Wǒ dăsuàn shuō dào Yīngguó liúxué

I plan say arrive UK study.abroad

'I planned to study abroad in the UK.'

\footnotetext{
* Thanks to Edith Aldridge, Shuheng Liu, Lu Shi, Chun Zheng, Karen Zagona, and audiences at LSA 2021 for helpful questions and comments on previous versions of this work. All errors are mine. Author: Jiahui Huang, University of Washington at Seattle (huangjh@uw.edu).

${ }^{1}$ Mandarin Chinese here refers to Beijing Mandarin specifically. Chappell (2008) reports that shuō is attested in Beijing Mandarin and Taiwanese Mandarin, but not in Standard Mandarin or Pǔtōnghuà. This paper focuses on the non-standard varieties of Mandarin in which the non-lexical usage of shuō has been more widely documented.
} 
On the basis of the distributional pattern of shuo in (1b), there has been a tradition in analyzing shuo (and their counterparts in other Sinitic languages) as a complementizer (Yeung 2006; Hsieh \& Sybesma 2008). However, this is by no means an undebatable conclusion, which has been challenged by some problematic cases where shuō cannot occur in clausal subjects, which is an environment that should be possible if shuō is a genuine complementizer (Paul 2014). Recent analyses make a further observation that shuō occurs not only in finite clauses (1b), but nonfinite clauses (1c), and defend the position of $s h u \bar{o}$ as a complementizer by analyzing shuō as a verbal suffix at PF (N. Huang 2018), which can arguably cover some atypical patterns compared to genuine complementizers.

In this paper, I claim that shuō is a complementizer (C), and crucially that shuō introduces a specific type of CP called non-referential CPs, in the sense of de Cuba (2017). By looking into the patterns of shuō in more detail, I show that there exist environments in which shuō is consistently ruled out, which suggests that shuō only introduces a subtype of clauses (including finite and non-finite clauses), that are non-referential. This proposal then argues that shuō is not entirely optional (cf. Chappell 2008) and that the two variants of shuo that occur in both finite and nonfinite clauses can be unified (cf. Huang 2018).

The paper is organized as follows. Section 2 reviews recent proposals about the syntactic status of the $s h u \bar{o}$. Section 3 presents an overview of the data patterns in more detail, with the special focus on the environments where shuō cannot occur, which has not been discussed in previous analyses. Section 4 discusses the notion of (non)referential CPs in the sense of de Cuba (2017) and their attestation in Mandarin Chinese. Section 5 discusses the optionality of shuō. Section 6 proposes the syntactic position for shuo and its implications for the atypical patterns of shuo as a complementizer. Section 7 discusses the predictions that this proposal makes towards the counterparts of shuo in other Sinitic languages. Section 8 concludes the discussion.

2. Is shuō a complementizer? There has been a tradition in analyzing shuō as a complementizer, which can be evidenced by the syntactic tests such as aspect marking (2a) and constituency test (2b), borrowing Yeung's diagnostics for the Cantonese semi-complementizer waa6 (Yeung 2006).

$$
\begin{aligned}
& \text { a. 張三 以為 說-(*過) 李四沒 來 } \\
& \text { Zhāngsān yǐwéi shuō-guo Lǐsì méi lái } \\
& \text { Zhāngsān believe say-ASP Lǐsì NEG come } \\
& \text { b. 張三 想-著 說 今天 不-去 並且 說 明天 也 不-去 } \\
& \text { Zhāngsān xiăng-zhe shuō jīntiān bù-qù bìngqiě shuō míngtiān yě bú-qù } \\
& \text { Zhāngsān think-DUR say today NEG-go and say tomorrow also NEG-go } \\
& \text { 'Zhāngsān is thinking that he is not going today and that he is not going tomorrow.' }
\end{aligned}
$$

First, the fact that the shuo following the verb yǐwé 'believe' cannot be aspectually marked in (2a) suggests that shuō lost its verbal property and acts as a complementizer. Second, while the constituency test in (2b) cannot directly target the complementizer status of $s h u \bar{o}$, the fact that shuō can form a constituent with the following complement in conjunction falls out naturally if shuō is analyzed as a complementizer that introduces clausal complements.

Paul (2014), on the other hand, provides counterexamples that constitute serious challenges to the complementizer approach (this part of review is modified based on N. Huang's 2018 paper). First, shuō cannot appear in fronted embedded clauses in afterthought constructions (3a); Second, shuō cannot head a sentential subject (3b); Third, shuō cannot be stranded (3c); Finally, 
there is often a pause after shuō, but crucially not between $s h u \bar{o}$ and the preceding verb (cf. (2b)). $\mathrm{N}$. Huang further observes that shuō cannot appear in the clausal complement of a noun (3d).
a. *(說) 生活-裡 缺-了 點-兒 什麼 我 總是 覺得
Shuō shēnghuó-lǐ quē-le diăn-r shénme wǒ zǒngshì juédé
say life-in lack-PERF little what I always feel
Intended: 'That something is missing in life, I have always thought so.'
b. *(說) 李四不-會 出席 會議 使 大家 感到 很 驚訝
Shuō Lǐsì bú-huì chūxí huìyì shǐ dàjiā găndào hěn jīngyà
say Lǐsi NEG-will attend meeting make all feel very surprised
Intended: 'That Lisi won't be attending the meeting surprised everyone.'

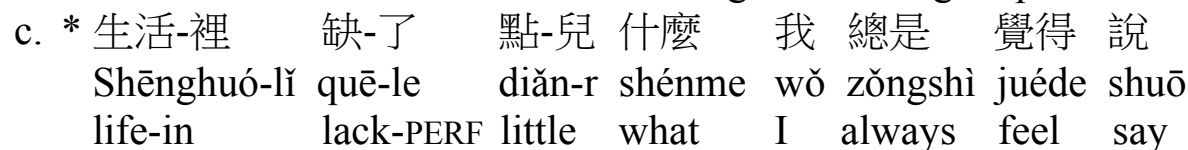

d. 總裁 否認了 ( *說) 公司 將 裁員 的 謠言

Zǒngcái fǒurèn-le say gōngsī jiāng cáiyuán de yáoyán

CEO deny-PERF say company will lay.off DE rumour

'The CEO denied rumours that the company will lay off workers.'

(Paul 2014: 98)

(N.Huang 2018: 369)

This set of examples on the surface undermines the complementizer approach since a genuine complementizer like English that does not exhibit this restriction, as shown in the translation in $(3 \mathrm{a}, 3 \mathrm{~b}, 3 \mathrm{~d})$. N. Huang (2018) recently proposes an analysis in defense of shuō as a complementizer while aiming to explain the problematic cases in (3a-3d). First, he proposes that there exist two variants of shuō that occur in finite (e.g., complements introduced by verbs such as y̌̌wéi 'believe') and non-finite contexts (e.g. complements introduced by verbs such as dăsuàn 'plan') respectively, as shown in (1b) and (1c), due to different sets of syntactic properties related to either of the contexts respectively. Second, he specifically analyses shuo as a verbal suffix at PF, following Bošković \& Lasnick's (2003) analysis of null C in English, which shows similar patterns in being disallowed in clausal subjects or in clausal complements of nouns. With shuō being a verbal suffix, it must immediately follow a verb when syntactic structures are linearized at PF. This proposal then accounts for the ungrammaticality in (3a) and (3b) with shuo at the sentential-initial position ${ }^{2}$, because in these two cases there are no preceding verbs that the shuo can attach to, as well as the pro-sodic pattern that shuo forms a unit with the preceding verb. For (3d), Huang argues that there exist some functional elements in the embedded left periphery that prevents $s h u \bar{o}$ from suffixing onto the preceding verb.

Two further implications of Huang's analysis are (i) shuo can basically co-occur with all kinds of verbs as a suffix at PF so long as there is not intervening material between the verb and $s h u \bar{o}$, and (ii) the two variants of $s h u \bar{s}$ in finite and non-finite clauses are two different elements syntactically. This paper proposes an alternative approach by obtaining a more comprehensive picture of data surrounding shuō. It will be shown that shuō consistently fails to occur in a set of environments, which is left unexplained in the existing analyses. The renewed look at the pattern

\footnotetext{
${ }^{2}$ Note that Paul (2014) uses the fact that shuō cannot be stranded (3c) to argue against the complementizer analysis. However, as Huang (2018: 371) notices that 'there appears to be a general constraint against standing complementizers (Abel 2003)', even for English that. Thus, I set aside this restriction in the following discussion in this paper.
} 
of shuō in turn points to a unified analysis of the two shuo that occur in finite and nonfinite contexts, which then explains the atypical patterns of shuō shown in (3) as a complementizer.

3. Data Patterns in more detail. Previous literature offers a large corpus documenting the environments where shuō can occur, which is conditioned by the degree of grammaticalization. Chappell $(2008,2017)$ offers an implicational hierarchy of verb classes that can co-occur with semi-complementizers in Sinitic languages (including shuō in Mandarin), which can be divided into five stages (4).

(4) Stage I (Quotative constructions) $\rightarrow$ Stage II (Speech act verbs, e.g. 'ask', 'tell') $\rightarrow$ Stage III (Cognition verbs, e.g., 'think') $\rightarrow$ Stage IV (Perception, emotion, and stative verbs, e.g. 'be worried') $\rightarrow$ Stage V (Modal verbs, e.g. 'be necessary').

Chappell $(2008,2017)$ argues that the shuo in Beijing Mandarin has reached Stage IV, by which shuo can occur not only in quotative constructions (the least grammaticalized stage) and speech act contexts (5a), but crucially in complements introduced by cognition verbs such as the verb juéde 'feel' (1b), repeated in (5b), and perception, emotion, or stative verbs, such as dānxīn 'be worried'(5c), which renders the lexical usage of shuō 'say' highly unlikely. Chappell also notices that the shuo in Taiwanese Mandarin exhibits even a higher degree of grammaticalization by which it can co-occur even with modal verbs, signaling that it has reached Stage V, but no examples are provided ${ }^{3}$.
a. 他 就 告訴 說 他 姑姑 來了
Tā jiù gàosù shuō tā gūgu lái le
he then tell say he aunt come ASP
'He then told that his aunt had came.'
$\begin{array}{lllll}\text { b. 我 總是 覺得 說 生活-裡 } & \text { 缺-了 } & \text { 點兒 什麼 } \\ \text { Wǒ zǒngshì juéde shuō shēnghuó-lǐ quē-le } & \text { diănr shénme }\end{array}$
I always feel say life-in lack-PERF little something
'I've always felt that there is something a bit lacking in my life.'
$\begin{array}{llllll}\text { c. 他 就 會 擔心 } & \text { 說 這-個 孩子 以後 } & \text { 會 怎麼樣 } \\ \text { Tā jiù huì dānxīn } & \text { shuō zhè-ge háizi yìhòu } & \text { huì zěnmeyang }\end{array}$
he then will be.worried say this-CL child afterwards will how
'He is then worried that how this child will become afterwards.'

(Beijing Mandarin from Fāng (2006))

To summarize, shuō in Mandarin (including both Beijing and Taiwanese Mandarin) can cooccur with a wide range of verbs. These distributional patterns form the basis for the existing syntactic analyses (see Section 2). However, no special attention has been paid to the environ-

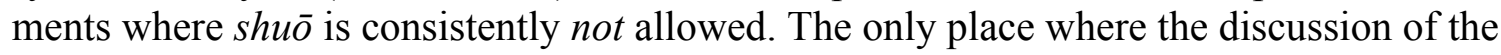
environment where shuo cannot occur is one note made by Chappell in which she claims that when the grammaticalization of semi-complementizers reaches upon the Stage V (e.g., modal

\footnotetext{
${ }^{3}$ In Chappell's documentation of the shuo counterparts in other non-Mandarin Sinitic languages, Hakka $k o \eta^{3 l}$ has reached Stage II, Cantonese waa6 has reached Stage III, Taiwanese Southern Min $k o \eta^{51}$ has reached Stage V, which is the most highly grammaticalized complementizer of all the Sinitic languages, as shown by the well-attested cooccurrence between $k o \eta^{51}$ and modal verbs (i).

(i) I thâu-náu hó bô-it-tēng $k o \eta^{51}$ I toh gâu chò seng-lí. 3SG brains good NEG.necessary say 3SG then clever do business 'Having good brains does not necessarily mean that you are good at business.'

(Chappell 2017)
} 
complements), 'expansion of verb classes taking the complementizer to other kinds of factive verbs may take place, with the potential of broadening the scope of further verb classes in an unrestricted manner (Chappell 2008: 62)'. In other words, factive verbs seem to behave as a cutting point along the scale of grammaticalization, after which the grammaticized complementizer can finally behave like a genuine complementizer. Interestingly, existing literature similarly shows the deficiency in detailed documentations of shuo occurring in factive complements.

This paper tries to fill the gap by exactly offering a more detailed look at the environments where shuō cannot occur. My data collection of Beijing Mandarin indicates that the shuōs occurring in complements introduced by factive verbs such as emotive factives like gāoxing 'be happy'/shāngxīn 'be sad' and hòuhǔ̌ 'regret'/făngăn 'resent', , are generally degraded compared to all the attested contexts (Stage I -V), which are all non-factive, as shown in (6) and (7).

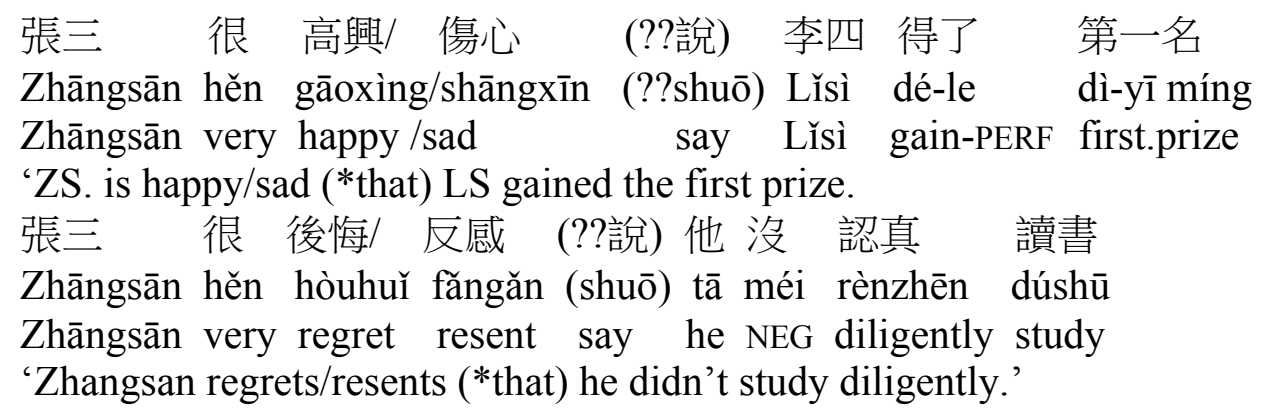

In other words, the occurrence of shuō is not random. In particular, shuō is incompatible with factive contexts and all the attested examples are those shuo that occur in non-factive contexts. It is unclear how the existing approach can capture this distributional discrepancy of shuō. In particular, N. Huang's approach that analyzes $s h u \bar{o}$ as a $\mathrm{C}$ and a verbal suffix predicts that shuō is allowed to appear so long as there exists a verb that it can attach to in LF. In Section 4, I will argue that the very fact $s h u \overline{\text { is }}$ ruled out in factive contexts suggests that shuo heads a specific type of CP, which in turns explains the problematic cases Paul (2014) reports in (3) and the two variants of shuō in finite and non-finite contexts (1b) and (1c).

4. Referentiality of CPs. Recall from Section 2 and Section 3 that the attested instances of complementizer shuō mainly occur in non-factive contexts, shuō occurring in factive contexts are generally degraded. de Cuba \& Ürögdi (2009), de Cuba \& MacDonald (2013) and de Cuba (2017) argue that factivity does not operate in syntax. Instead, it is the referentiality of the CP that distinguishes the so-called factive and non-factive clauses. The definitions of referential CPs and non-referential CPs, in the spirit of de Cuba (2017), are recounted in (8). The factive clauses in traditional sense are replaced by 'Referential CPs' in this view.

a. Referential CPs: an accepted (or pre-established) proposition in the existing discourse which has no illocutionary force.

b. Non-referential CPs: a speech act which introduces a proposition (or an open question) which is not yet accepted (or pre-established) in the existing discourse.

(de Cuba: 2017: 27)

\footnotetext{
${ }^{4}$ Note that my data collection indicates that shuō is compatible with complements introduced by semifactive verbs such as 'know'. I will leave the distinction between emotive factives and semifactives with regard to their behavior in co-occurring with shuō for future research.
} 
One immediate question of adopting this proposal is that whether there exists independent evidence for the referentiality distinction in the clausal domain in Chinese. de Cuba \& MacDonald (2013) present two diagnostics in distinguishing referential CPs from non-referential CPs, one is whether there exists a difference between the two subtypes of clause in requiring discourse context: Referential CPs requires discourse context and cannot be used in out-of-the-blue-contexts; By contrast, non-referential CPs can be used in out-of-the-blue-contexts. This contrast is attested in Mandarin Chinese (9) where a context in which a child stole a book from the library is provided (assuming this is a context where a teacher is meeting with the child's parents).

Context:

$$
\begin{aligned}
& \text { 你-的 孩子 今天 偷-了 } \quad \text { - } \text {-本 書 } \\
& \text { Nǐ-de háizi jīntiān tōu-le yì-běn shū } \\
& \text { your child today steal-PERF one-CL book } \\
& \text { 'You child stole a book today.' }
\end{aligned}
$$

a. 我很抱歉/ 遺喊 我-的孩子今天 偷-了 一-本 書

Wǒ hěn bàoqiàn/yíhán wǒ-de háizi jīntiān tōu-le yì-běn shū

I very sorry/ regret my child today steal-PERF one-CL book

'I am sorry/regret that my child stole a book today.'

b. 我 覺得/ 以為 我的 孩子今天 偷-了 一-本 書

Wǒ juéde/y̌̌wéi wǒ-de háizi jīntiān tōu-le yì-běn shū

I feel/ believe my child today steal-PERF one-CL book

'I am sorry/regret that my child stole a book today.'

(uttered by the parents)

Under the context provided in (9), only (9a) instead of (9b) is a possible response to the utterance made by the teacher. (9a) instantiates the referential CPs while (9b) exemplifies the nonreferential CPs. Since 'your child stole a book' is already accepted in the existing discourse, which makes the complements introduced by verbs such as juéde 'feel' or y̌wéi 'believe' that comes with a speech act introducing a proposition that is not accepted in the existing discourse inappropriate. There is no need to introduce a proposition that is already established in the context. This constitutes as the first piece evidence of a referentiality distinction in Mandarin Chinese.

The second diagnostic de Cuba \& MacDonald uses to distinguish referential CPs from nonreferential CPs is related to clausal anaphora: non-referential CPs allow both do-so placement and it-placement, the latter of which targets referential arguments only (10a); referential CPs by contrast only allows it-placement (10b). Similar examples can be identified in Mandarin Chinese (11) where zhèmeyang 'so' is available only under the non-factive/non-referential predicates (11a) but not factive/referential predicates (11b). This contrast between (11a) and (11b) similarly points to a referentiality distinction of clausal complements in Mandarin.

(10) a. John supposed [that Bill had done it], and Mary supposed [it/so] too.

b. John regretted [that Bill had done it], and Mary regretted [it/*so] too.
a.
我 認為/ 以為他很 聰明:
Wo rènwéi/yǐwéi tā hen cōngming;
I think/ think he very smart
they also so
'I thought that he was smart; they also thought *(so).'(A. Li, 2013: 214)
b. 我 很 後悔/ 討厭 他做-了 這樣-的 事;
Wǒ hen hǒuhuǐ/tăoyàn tā zuò-le zhèyàng-de shì;
I very regret/ resent he do-PERF this-kind-de thing

他們 也* (這麼樣)

認為/ 以為

tāmen yě (zhèmeyang)

rènwéi/yřwéi 


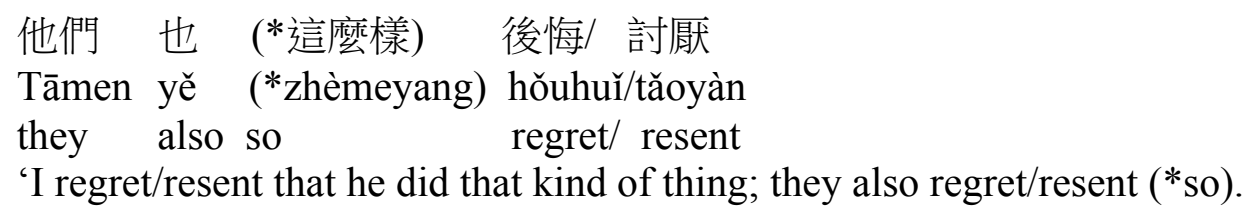

Finally, the preposition dui 'on' in Mandarin provides language-internal evidence for the referentiality distinction of clausal complements. Huang, $\mathrm{Li}, \mathrm{Li}$ (2009) treats dui 'on' as a diagnostic to distinguish adjectives from verbs: Many adjectives in Mandarin require prepositional phrases headed by dui 'on' followed by the preposed object when they are used transitively (12).
a. 這-個 工作 對 妳 很 合適
Zhè-ge gōngzuò duì nǐ hen héshì
this-CL job on you very suitable
'This job is stuitable for you.'
*Zhe-ge gōngzuò hen héshì nì
this-CL job very suitable you (Huang, Li, Li 2009: 22)
b. *這-個 工作 很 合適 你

Interestingly, parallel to the two-way distinction based on referentiality of CPs shown in (9) and (11), only the referential predicates are allowed to co-occur with PPs headed by dui (13a); non-referential predicates are incompatible with PPs headed by dui (13b).
a. 張三 對她 做-了 這樣-的 事 很 反感
Zhāngsān duì tā zuò-le zhèyáng-de shì hěn făngăn
Zhāngsān on she do-PERF this.kind-MOD thing very resent
'ZS resents that he had done this kind of thing.'
b. *張三 對 李四 去-了 郵局 以為
*Zhāngsān duì Ľ̌sì qù le yóujú y̌rwéi
Zhāngsān on Lǐsì go-PERF post.office believe

Combining the three diagnostics, clausal complements in Mandarin Chinese clearly exhibit a referentiality distinction. Thus, adopting this updated view of clausal complements, I restate the generalization reached in Section 3 using the referential/non-referential distinction in the CP domains: shuō only occurs in non-referential CPs but not referential CPs. To put it differently, shuō heads a subtype of clauses, namely non-referential $\mathrm{CPs}$, which then explains the unacceptability of $s h u \bar{o}$ that occurs in referential CPs (introduced by verbs such as emotive factive verbs like gāoxing 'be happy'/shāngxīn 'be sad' and hòuhuľ 'regret'/făngăn 'resent').

5. Non-referential CP with or without shūo. It has been established in the literature that $s h u \bar{o}$ is optional (Chappell 2008). The clausal complements with shuō and the one without shuō are argued to be interchangeable. A further scrutiny of the data pattern suggests that shuō is not optional, at least for complements introduced by non-speech act verbs (such as dānxīn 'be worried' and dăsuàn 'plan', which make the shuō very unlikely to be interpreted in its quotative usage).

de Cuba \& MacDonald (2013) report that the apparent optional complementizer que with preguntar in Spanish is in fact not optional at all. The presence of que suggests a presence of a speech-act operator that introduces a proposition into the common ground (which is not shared by the speakers). The minor yet significant difference between the one with the que and the one without is that the latter clause is an initial attempt on the part of the speakers to introduce the proposition to the common ground while the former clause instead is a non-initial attempt to 
introduce the following proposition into the common ground. Put it differently, there are two subtypes of non-referential CPs that both introduce unsettled propositions to the common ground but in slightly different ways: the non-referential CPs without que is used in a context where the proposition is introduced by the speaker to the common ground for the first time; By contrast, the non-referential CPs with que can be uttered when the proposition introduced by the que should already be shard and accepted in the context from the point of view of the speaker but somehow has not yet been totally accepted in the common ground. Under a well-defined context, the difference between the two can be distinguished. (14) shows a similar case from shuō in Mandarin Chinese, with the verb dăsuàn 'plan' as an illustration.

(14) Context: Lissì is sharing a travel plan with his friends, who thought Lissì will have to stay in town because he needs to prepare for an important exam and plus there will still be many travel restrictions due to the pandemic.
a. 李四 打算 說 年底到 歐洲 度假
Lǐsì dăsuàn shuō niándǐ dào Ōuzhōu dùjià
Lǐsì plan say year.end to Europe go.on.vacation
'Lisi plans to take a vacation in Europe at the end of the year.'
b. 李四 打算 年底 到 歐洲 度假
Lǐsì dăsuàn niándǐ dào Ôuzhōu dùjià
Lǐsì plan year.end to Europe go.on.vacation
'Lisi plans to take a vacation in Europe at the end of the year.'

While (14a) and (14b) are both possible independently, under the context described in (14), only the instance without the shuō is appropriate. This is expected if the variant with shuō in (14a) reflects a 'non-initial' attempt on the part of the speaker to (re)introduce the following proposition (which should already be accepted in the common ground from the point of view of the speaker), which is incompatible with the context in (14) where the following proposition 'going on vacation in Europe' has never part of the common ground (in fact, the context is completely opposite to what is accepted in the common ground (that Lissì is staying in town)). This suggests that the presence or absence of shuo conveys two different interpretations, contra previous analyses that analyze shuō as a completely optional element in introducing clausal complements.

6. Syntactic positions of shūo. Having established that shuō heads a subtype of non-referential CPs, which is not entirely interchangeable with the clausal complement without shuo, this section provides an analysis of the syntactic positions of shuō.

There are at least two major approaches for referential CPs (which subsume factive CPs in the traditional sense). The first one comes from de Cuba's own truncation approach in which referential CPs are those with an impoverished left periphery (15b) while non-referential CPs with a full periphery (15a) (see Haegeman 2006 also).

$$
\begin{aligned}
& \text { a. } \mathrm{V}[\mathrm{cP}[\mathrm{CP}]] \\
& \text { b. } \mathrm{V}[\mathrm{CP}] \quad \text { (de Cuba \& Ürögdi 2009: 37) }
\end{aligned}
$$

Haegeman \& Ürögdi (2010) instead argue that referential clauses are the result of an operator movement (which derives the referentiality in the clausal domain) (16) in the left periphery compared to the lack of it in non-referential clauses.

$$
\left.\left.\left[\mathrm{CP} O \mathrm{OP}_{\mathrm{i}} \mathrm{C} \ldots\right]_{\mathrm{FP}} \mathrm{t}_{\mathrm{i}}[\mathrm{TP} \ldots]\right]\right] \text { (Haegeman \& Ürögdi, 2010: 115) }
$$


Given the unsettled status of referential clauses, I remain non-committal about the final implementation of these clauses ${ }^{5}$. Regardless, both lines of approach agree that there is a referentiality distinction in the $\mathrm{CP}$ domains, which I argue is the key to the understanding some of the unexpected patterns of shuō in Mandarin as a complementizer. Specifically, following Melvold's (1991) proposal that referential clauses are encoded with [+definite] features whereas non-referential CPs with [-definite] feature ${ }^{6}$. I argue that shuō heads a specific type of non-referential CPs with a [-definite] feature (17a), whereas the referential CPs are headed by an obligatorily null C with a [+definite] feature (17b), hence the unacceptability of shuo in referential clauses.

$$
\begin{array}{ll}
\text { a. } & {\left[\mathrm{V} \ldots\left[\mathrm{C}_{[-\mathrm{DEF}]} \operatorname{shu\overline {o}\ldots ]}\right]^{7}\right.} \\
\text { b. } & {\left[\mathrm{V} \ldots\left[\mathrm{C}_{[+\mathrm{DEF}]} \emptyset \ldots\right]\right]}
\end{array}
$$

With shuō heading a [-def] clausal complement while the referential CP headed by an obligatorily null $\mathrm{C}$ with a [+def] feature, some patterns atypical of $s h u \bar{o}$ as a complementizer fall out naturally. Recall that Paul (2014) presents examples that (i) embedded clauses headed by shuo cannot be fronted in afterthought constructions (3a) (ii) shuō cannot appear in clausal subjects (3b), unlike typical complementizers such as English that. More examples are shown in (18a) and (18b), respectively.
a. (*說) 李四 會 來, 我 以為
(Shuō) Lǐsì huì lái, Wǒ yǐwéi
say Lǐsì will come I believe
Intended Reading: 'That Lǐsì will come, I believe.'
b. (*說) 李四 退學 讓 家裡人 很擔心
(Shuō) Lǐsì tuìxué ràng jiālǐrén hěn dānxīn
say Lǐsì drop.out make home.people very worried
'(*That) Lǐsì dropped out worries his family a lot.'

The impossibility of shuo occurs in (18a) and (18b) is accounted for in the current proposal by the [-def] feature in the sentence-initial position, because Mandarin generally disallows

\footnotetext{
${ }^{5}$ The fact that referential clauses introduced by factive verbs such as hòhul 'regret' permits Main Clause Phenomenon (e.g. inner topics) in Mandarin (i) gives a plus to the operator movement approach and a minus to the truncation approach. It is unclear how a truncation approach accounts for the acceptability of inner topics within the factive clauses if the left periphery are truncated.

(i) 我 很 遺憾 那-本 書 你 沒 讀-過

Wǒ hen yíhàn nà-běn shū ní méi dú-guo

I very regret that-CL book you NEG read-ASP

'I regretted that you haven't read the book.' (Liao \& Kao 2017)

${ }^{6}$ Melvold's original approach uses the traditional factive/non-factive distinction. Here I change the factivity distinction to a referentiality distinction, following de Cuba (2017).

${ }^{7}$ Recall in Section 5, adopting de Cuba \& MacDonald's analysis of preguntar 'ask' with que in Spanish, I present evidence that the absence or presence of shuo in similarly not optional. While they both introduce new and unsettled propositions (therefore non-referential), but the propositions introduced are slightly different, namely, they introduce proposition as either the first-attempt or the non-initial attempt from the perspective of the speaker, respectively. The difference between the two can be captured along the line of cartographic approach by which shuō, similar to que in Spanish, is analyzed as the head of an extended projection in the CP licensed by a speech-act operator (de Cuba \& MacDonald 2013: 137), which is absent in the non-referential CPs without shuō.
} 
indefinite subjects in clause-initial positions, which is a well-discussed fact in the syntax of Chinese (Huang, Li \& Li, 2009), as shown in (19).

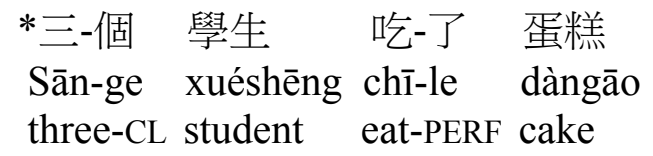

It can be predicted that (18a) and (18b) without the sentential-initial shuo are acceptable with a [+def] reading, which cannot be used without discourse context. This is borne out in (20) in which a context where the participant of the embedded clause has not been established in the discourse. Only the clausal complements in its postverbal position (20b) can be used in this context, since the embedded proposition needs to be introduced to the common ground for the first time by the speakers. (20a) with the fronted clause requires a context where Lisi is already shared in the common ground, which is incompatible with the out-of-the-blue context in (20).

(20) Context: Assuming Lisi has never been brought up in the discourse context (no one knows who Lisi is).
a. \#李四 會 來, 我 以為
Lǐsì huì lái, Wǒ yřwéi
Lǐsì will come I believe
'That Lǐsì will come, I believe.'
b. 我 以為 李四 會 來
Wǒ yǐwéi Lǐsì huì lái
I believe Lǐsì will come
'I believe Lǐsì will come.'

This proposal then unifies the two variants of shuo that occur both in finite and nonfinite clauses, as shown in (1b) and (1c), repeated in (21), because they both introduce non-referential CPs (introduced by non-factive verbs). Recent discussions on control (e.g. Landau, 2015) propose that there also exists a left periphery that represents the context of speech for attitude complements (e.g. dăsuàn 'plan') in C, or a 'logophoric center' in the sense of Bianchi (2003), which are available for both finite and attitude nonfinite contexts (e.g. external logophoric center for finite clauses while internal logophoric center for nonfinite clauses). I argue that shuo exemplifies this $\mathrm{C}$ head for both for (21a) and (21b).
a. 我 總是 覺得 說 生活-裡 缺-了 點-兒 什麼
Wǒ zǒngshì juéde shuō shēnghuó-lǐ quē-le diăn-r shénme
I always feel say life-in lack-PERF little something
I've always felt that there is something a little lacking in my life.' (Fāng, 2006: 109)
b. 我 打算 說 到 英國 留學
Wǒ dăsuàn shuō dào Yīngguó liúxué
I plan say arrive UK study.abroad
'I planned to study broad in the UK.'

7. Predictions for other Sinitic languages. Recall this current analysis proposes that the fact that shuo heads a non-referential CP accounts for the atypical patterns of shuo being unable to occur in sentential initial position, due to an independent restriction in syntax of Chinese where indefinite subjects are disallowed in sentence-initial position. Given that shuō as a 


\section{d. 安呢 共趕 伊 走安-呢啦 an2-ni1 ka7 kuann2 i1 tsau2 an2-ni1 lah8 so OBL expel 3SG go so SFP 'He is also embarrassed that he expels him.' (Tseng 2008: 99)}

8. Conclusions. In this paper I have claimed that shuō is a semi-complementizer that introduces non-referential CPs based on a revisit of the distributional patterns between shuo and different clausal complements. The atypical patterns observed in the previous literature can be explained by the non-referential/indefinite feature of the clauses headed by shuō. This paper also provides predictions for the analysis of other semi-complementizers that are grammaticalized from verbs of saying in other Sinitic languages. It remains to be seen how such an account can be extended to the rich cross-linguistic patterns of (semi)-complementizers of the similar kinds. This issue is however outside the scope of this paper and must be left to further investigation.

\section{References}

Bianchi, Valentina. 2003. On finiteness as logophoric anchoring. In Jacqueline Guéron \& Liliane Tasmowski (eds.), Temps et point de vue [Tense and point of view], 213-246. Paris: Université Paris X.

Bošković, Želijko \& Howard Lasnik. 2003. On the distribution of null complementizers. Linguistic Inquiry 34(4). 527-546. https://doi.org/10.1162/002438903322520142.

Burukina, Irina. 2021. Arguments introduced by C heads. Paper presented at the 2021 Annual Meeting of the Linguistic Society of America.

Chappell, Hilary. 2008. Variation in the grammaticalization of complementizers from verba dicendi in Sinitic languages. Linguistic Typology 12(1). 45-98.

https://doi.org/10.1515/LITY.2008.032.

Chappell, Hilary. 2017. Say-complementizers: shuō 說, waa3 話, kong1 講. In Rint Sybesma (ed.), Encyclopedia of Chinese language and linguistics. London: Brill. https://doi.org/10.1163/2210-7363_ecll_COM_00000098.

Cheng, Robert. 1997. The constructional markers shuo 'say'and kan 'see' in Taiwanese and Taiwan Mandarin. In Taiwanese and Mandarin structures and their developmental trends in Taiwan II: Contacts between Taiwanese and Mandarin and restructuring of their synonyms. 105-131. Taipei: Yuan-Liou Publishing.

de Cuba, Carlos \& Barbara Ürögdi. 2009. Eliminating factivity from syntax: Sentential complements in Hungarian. In Marcel den Dikken \& Robert M. Vago (eds.), Approaches to Hungarian (Volume 11: Papers from the 2007 New York Conference), 29-63. Amsterdam: John Benjamins. https://doi.org/10.1075/atoh.11.

de Cuba, Carlos \& MacDonald, Jonathan. 2013. Referentiality in Spanish CPs. In Victoria Camacho-Taboada, Ángel L. Jiménez-Fernández, Javier Martín-González \& Mariano Reyes-Tejedor (eds.), Information Structure and Agreement, 117-140. Amsterdam: John Benjamins. https://doi.org/10.1075/la.197.

de Cuba, Carlos. 2017. Noun complement clauses as referential modifiers. Glossa: A Journal of General Linguistics 2(1). 3. https://doi.org/10.5334/gjgl.53. 
Fāng, Méi. 2006. 北京话里“说”的语法化-从言说动词到从句标记 (Beijinghua-li 'shuo'de yufahua-cong yanshuo dongci dao congju biaoji) [Grammaticalization of shuō (say) in Beijing Mandarin: from lexical verb to subordinator]. 中国方言学报 Zhongguo Fangyan Xuebao 1. 107-121.

Haegeman, Liliane \& Barbara Ürögdi. 2010. Referential CPs and DPs: An operator movement account. Theoretical Linguistics 36( 2-3). 111-152. https://doi.org/10.1515/thli.2010.008.

Haegeman, Liliane. 2006. Conditionals, factives and the left periphery. Lingua 116(10). 16511669. https://doi.org/10.1016/j.lingua.2005.03.014.

Bernd, Heine \& Tania Kuteva. 2002. World lexicon of grammaticalization. Cambridge: Cambridge University Press.

Hock, Hans Heinrich. 1982. The Sanskrit quotative: A historical and comparative study. Studies in the Linguistic Sciences 12(2). 39-85.

Heish, Feng-fan \& Rint Sybesma. 2009 生成语法理论与汉语语气词研究 (Shēngchéng yǔfã lǐlùn hé Hànyǔ yǔqì yánjiūcí yánjiū). In Yáng Shěn \& Shènglì Féng (eds.), 当代语言学理论 和汉语研究 Dāngdài yǔyánxué lǐlùn hé hànyǔ yánjiū [Contemporary linguistic theories and related studies on Chinese], 364-374. Peking: Shāngwù.

Huang, Nick. 2018. Control complements in Mandarin Chinese: Implications for restructuring and the Chinese finiteness debate. Journal of East Asian Linguistics 27(4). 347-376. https://doi.org/10.1007/s10831-018-9185-1.

Huang, Cheng-The James \& Yen-hui Audrey Li \& Yafei Li. 2009. The syntax of Chinese. Cambridge: Cambridge University.

Huang, Yanxuan. 2016. 揭陽方言言說動詞“呾”的語法化(Jiēyáng fāngyán yánshuō dòngcí da de yŭfăhuà) [Grammaticalization of the SAY verb $d a$ (呾) in the Jieyang dialect]. 中国語 文 Zhōngguō Yǔwén 6. 686-694.

Li, Yen-hui Audrey. 2013. Case, tense and clauses. In Guangshun Cao, Hilary Chappell, Redouane Djamouri \& Thekld Weilbusch (eds.), Breaking down the barriers: Interdisciplinary studies in Chinese linguistics and beyond, 205-325. Taipei: Institute of Linguistics, Academia Sinica.

Liao, Wei-wen Roger \& Kao, Grant. 2017. Argumenthood, MCP, and Chinese topicalization. Presentation at International Association of Chinese Linguistics 25. Hungarian Academy of Sciences and Eötvös Loránd University.

Lien, Chinfa. 2020. Kong2 as a verb for saying 'on the move' in Taiwanese Southern Min. In Chinfa Lin \& Alain Peyraube (eds.). Diachronic [erspectives and synchronic variation in Southern Min, 197-216. London: Routledge. https://doi.org/10.4324/9780429316517.

Lin, Huáyǒng \& Má, Zhé. 2007. 廉江方言言說義動詞“講”的語法化(Liánjiāng fāngyán yánshuōyì dòngcí jiăng de yŭfăhuà) [Grammaticalization of the speech verb (講) in the Liánjiāng dialect of Guangdong Province]. 中国語文 Zhōngguō Yǔwén 7. 151-158.

Melvold, Janie. 1991. Factivity and definiteness. MIT Working Papers in Linguistics 15. 97-117. Paul, Waltraud. 2014. Why particles are not particular: Sentence-final particles in Chinese as heads of a split CP. Studia Linguistica 68(1). 77-115. https://doi.org/10.1111/stul.12020.

Simpson, Andrew \& Zoe Wu. 2002. IP-raising, tone sandhi and the creation of S-final particles: Evidence for Cyclic Spell-Out. Journal of East Asian Linguistics 11. 67-99. https://doi.org/10.1023/A:1013710111615. 
Xu, Huiling \& Stephen Matthews. 2007 .從動詞到子句標記：潮州方言和台灣閩南語動詞“ 說”和“看”的虛化過程 (Cóng dòngcí dào zìjù biāojì: Cháozhōu fāngyán he Táiwān Mǐnnányǔ 'shuō' hé 'kàn' de xūhuà guòchéng) [From verb to complementizer: the grammaticalization process for verbs 'say' and 'see' in the Chaozhou dialect and Taiwanese Southern Min]. 中国語文研究 Zhōngguō Yǔwén Yánjiū 23. 61-72.

Yeung, Ka-Wai. 2006. On the status of the complementizer waa6 in Cantonese. Taiwan Journal of Linguistics 4(1). 1-48. 